\title{
OBESITY AND LIFESTYLE FACTORS AS DETERMINANTS OF TYPE 2 DIABETES MELLITUS IN MANADO CITY, INDONESIA
}

\author{
Grace D. Kandou ${ }^{1 *}$, Budi T. Ratag ${ }^{1}$, Angela F.C. Kalesaran ${ }^{1}$ and Priscilla C. Kandou ${ }^{1}$ \\ ${ }^{1}$ Faculty of Public Health, Sam Ratulangi University, Manado, Indonesia \\ ${ }^{*}$ Corresponding Author: Grace D. Kandou \\ E-mail: grace.kandou@unsrat.ac.id
}

\begin{abstract}
High prevalence of diabetes mellitus is caused by various factors such as lifestyle changes and obesity, and tends to be higher in urban than in rural areas. The aim of this study was to analyse obesity, physical activity, smoking, and family history as determinants of type 2 diabetes mellitus in Manado City, Indonesia. A matched case-control study of outpatients at five public health centres in Manado City from February to November 2018 was conducted; cases were patients who had been clinically diagnosed with type 2 diabetes mellitus and controls were those without a diagnosis, and these were matched in a 1:1 ratio based on age and sex. Simple random sampling was used with a total of 128 participants, and data were analysed by McNemar's test and conditional logistic regression. The results showed $p$-values for obesity of $<0.05$ (OR=7.75, 95\% Cl=2.73-21.95), for physical activity of $<0.05$ (OR=11.00, 95\% Cl=3.37-35.86), for smoking of $0.208(O R=1.58,95 \% \mathrm{Cl}=0.76-3.26)$, and for family history of diabetes mellitus of $<0.05(O R=7.00,95 \% \mathrm{Cl}=2.45$ 19.95). Multivariate modelling showed physical activity had the highest odds of causing to type 2 diabetes mellitus with $O R$ equals to 7.89. Significant associations were found between obesity, physical activity, and family history with physical activity returning the highest odds. Changes in lifestyle are highly recommended to prevent increased risk of type 2 diabetes mellitus, particularly to include frequent physical activity such as jogging, running, walking, or other aerobic exercise to increase insulin sensitivity.

Keywords: diabetes, obesity, physical activity, smoking, family history
\end{abstract}

\section{INTRODUCTION}

One of the targets of the UN's Sustainable Development Goals (SDGs) is to reduce by one third the early mortality rate from noncommunicable diseases (NCD) as part of several other health targets ${ }^{1}$. Diabetes mellitus (DM) is one of the NCDs with high case numbers, its global incidence continuing to rise annually. The latest data from the World Health Organization (WHO) shows that in 2000, 150 million of the global population suffered from DM and that this figure will double by $2025^{2}$.

In 20-79 year olds, the worldwide prevalence of DM has increased from $5.9 \%$ to $7.1 \%$ (246 to 380 people), although the relative proportions vary from 15:85 in developed countries to 5:95 in developing countries ${ }^{3}$. The WHO's 2014 'Global Status Report on Non-communicable Diseases' stated that the global prevalence of DM was $9 \%$ at that point. The proportion of deaths from DM is $4 \%$ with $80 \%$ of these occurring in low and middle income countries. In 2030, it is estimated that DM will rank as the seventh highest cause of death in the world ${ }^{2}$.

Based on WHO data, Indonesia has the 6th highest number of DM patients after India, China, America, Japan, and Brazil ${ }^{4}$. Recorded in 2005, the number of people with DM in Indonesia reached 5 million with an increase of 230,000 patients ${ }^{4}$. The International Diabetes Federation estimates that the number of people with DM in Indonesia will more than double from the $2,598,000$ recorded in 2007 to $5,210,000$ patients by 2025. The WHO describes this increase in, especially type 2 , DM patients as often experienced by developing countries, including Indonesia ${ }^{4}$. Type 2 DM and other insulin disorders tend to appear from the age of 45 because by this stage, the body has experienced many changes, specifically in the pancreas that produces insulin in the blood ${ }^{5}$.

In addition, DM is a risk factor for various major conditions such as coronary heart disease, heart failure, and stroke ${ }^{6}$. According to the American Diabetes Association, DM patients have a $40 \%$ risk of suffering from glaucoma and a $60 \%$ risk of cataracts compared to non-DM patients. Furthermore, people with DM are 1.5 times more likely to suffer stroke, and the risk of death for DM stroke patients is 2.8 times higher than non-DM patients ${ }^{7}$.

Many elements are considered risk factors for type $2 \mathrm{DM}$ and can be grouped into three categories, namely socio-demographic (e.g. age, gender, marital status, education level, occupation), clinical/mental (e.g. obesity, stress), and lifestyle factors (e.g. diet, physical activity, smoking, 
alcohol consumption $)^{8}$. According to the WHO, an unhealthy lifestyle is one of the ten primary causes of death and disability in the world.9 More than two million deaths are caused each year by a lack of physical activity. In such cases, the number of calories entering the body is not proportional to those that are burned meaning that they accumulate and cause physical deterioration and various diseases such as DM, hypertension, heart disease, and stroke?

The number of people with diabetes, especially type 2 DM, is increasing across the world, particularly in developing countries because of lifestyle changes and obesity ${ }^{5}$. The 2016 'Health Profile of North Sulawesi Province' ranked DM as 5 th of 10 prominent diseases through integrated health center surveillance with a total of 5,055 cases $^{10}$. Similarly, DM ranked 5th of 10 with 939 cases in a 2017 report for Manado City ${ }^{11}$. The purpose of this study was to analyze the risk of obesity, physical activity, smoking, and family history to type 2 DM events in Manado City, Indonesia.

\section{METHODS}

This research was a quantitative observational analytic study with case-control design conducted from February to November 2018 in five health centres in Manado City, namely the Bahu, Ranotana Weru, Tikala Baru, Sario, and Teling Atas health centers. These five centers were selected due to their relatively high numbers of DM cases in comparison with other health centres. As such, the study population was all patients (male and female) that visited any of the five centres in the study period; cases were patients with a 6-month clinical diagnosis of type 2 DM (December 2017 to May 2018) as identified through medical records and controls were patients who had no such diagnosis but who had visited the health centres during the study period. Cases were matched to controls in a 1:1 ratio based on age and sex, having been sampled using a simple random sampling technique. Control selection was established by attendance list and matching factors (age and sex). The results of the calculations using the Lemeshow sampling formula identified the minimum number of cases to be 64 , and, since this study uses a ratio of $1: 1$, the total sample included 128 participants.

The independent variables were obesity, smoking, physical activity, and family history of DM, and the dependent variable was type 2 DM events. The instruments used were a questionnaire, weight scales, and microtoise with accuracy of $0.1 \mathrm{~cm}$. The questionnaire was built from the standard 30 items in the Indonesian Ministry of Health's 'Basic health research' instrument which were adjusted to the current research variables. The sources for this study are the primary data obtained through direct interaction with the research subjects using questionnaires, weight scales, and microtoise, and the secondary data from health profiles, annual and monthly routine case reports of NCDs, and NCD patient lists obtained from the North Sulawesi Provincial Health Office, the Manado City Health Office, and the five participating health centres.

Bivariate analysis was carried out using McNemar's test and multivariate analysis with conditional logistic regression (CLR) which were implemented in light of the binary matched pairs and to investigate the association between an outcome being an event (case) or a non-event (control) and a set of prognostic factors. According to the Central Bureau of Statistics' 'Manado City in Figures 2018',12 Manado City is located at the northern tip of Sulawesi island; it is the capital of and the largest city in the province. The population of Manado City in 2017 was 430,133 which, in an area of $157.26 \mathrm{~km} 2$, represents a relatively high population density of 2,736 people $/ \mathrm{km}^{2}$.

\section{RESULTS}

The distribution of respondent characteristics can be seen in Table 1. The 55-64 age group can be seen as being most represented in both the case and control groups with a percentage of $37.5 \%$. Most case and control respondents were female with a percentage of $53.1 \%$.

\begin{tabular}{|c|c|c|c|c|c|c|}
\hline \multirow{3}{*}{ Characteristic } & \multicolumn{6}{|c|}{ Respondents } \\
\hline & \multicolumn{2}{|c|}{ Case } & \multicolumn{2}{|c|}{ Control } & \multicolumn{2}{|c|}{ Totals } \\
\hline & $\mathrm{n}$ & $\%$ & $\mathrm{n}$ & $\%$ & $\mathrm{n}$ & $\%$ \\
\hline $\begin{array}{l}\text { Age } \\
\text { (year) }\end{array}$ group & & & & & & \\
\hline $35-44$ & 9 & 14.1 & 9 & 14.1 & 18 & 14.1 \\
\hline $45-54$ & 18 & 28.1 & 18 & 28.1 & 36 & 28.1 \\
\hline $55-64$ & 24 & 37.5 & 24 & 37.5 & 48 & 37.5 \\
\hline $65-74$ & 13 & 20.3 & 13 & 20.3 & 26 & 20.3 \\
\hline$\geq 75$ & 0 & 0 & 0 & 0 & 0 & 0 \\
\hline Total & 64 & 100 & 64 & 100 & 128 & 100 \\
\hline Gender & & & & & & \\
\hline Male & 30 & 46.9 & 30 & 46.9 & 60 & 46.9 \\
\hline Female & 34 & 53.1 & 34 & 53.1 & 68 & 53.1 \\
\hline Total & 64 & 100 & 64 & 100 & 128 & 100 \\
\hline
\end{tabular}

The risk factors in this study are the independent variables of obesity, smoking, physical activity, and family history of DM. The details of these factors across the respondents in this study can be seen in Table 2. 
Table 2. Distribution of risk factors across respondents.

\begin{tabular}{|c|c|c|c|c|}
\hline \multirow{3}{*}{ Risk factor } & \multicolumn{4}{|c|}{ Respondents } \\
\hline & \multicolumn{2}{|c|}{ Case } & \multicolumn{2}{|c|}{ Control } \\
\hline & $\mathrm{n}$ & $\%$ & $\mathrm{n}$ & $\%$ \\
\hline \multicolumn{5}{|l|}{ Obesity } \\
\hline Yes & 46 & 71.9 & 19 & 29.7 \\
\hline No & 18 & 28.1 & 45 & 70.3 \\
\hline \multicolumn{5}{|l|}{ Smoking } \\
\hline Yes & 36 & 56.3 & 29 & 45.3 \\
\hline No & 28 & 43.7 & 35 & 54.7 \\
\hline \multicolumn{5}{|l|}{$\begin{array}{l}\text { Physical } \\
\text { activity }\end{array}$} \\
\hline Less & 48 & 75 & 18 & 28.1 \\
\hline Enough & 16 & 25 & 46 & 71.9 \\
\hline \multicolumn{5}{|l|}{$\begin{array}{l}\text { Family history } \\
\text { of DM }\end{array}$} \\
\hline Yes & 48 & 75 & 24 & 37.5 \\
\hline No & 16 & 25 & 40 & 62.5 \\
\hline
\end{tabular}

Table 2 shows that of the 128 respondents, 46 $(71.9 \%)$ cases were obese while $19(29.7 \%)$ controls were obese. Of the cases, $36(56.3 \%)$ smoked while $29(45.3 \%)$ controls also smoked. The number of cases who had less physical activity was 48 (75\%), but just $18(28.1 \%)$ of controls undertook less physical activity. A history of DM in the family was present in $48(75 \%)$ of cases and in $24(37.5 \%)$ of controls.

Bivariate analysis with $2 \times 2$ tables was applied to all independent variables in this study to determine the significance of association between them and type 2 DM events. The statistical test used was McNemar's test to calculate the odds ratio (OR) of each with confidence interval $(\mathrm{Cl})$ of $95 \%$. The results of this bivariate analysis between the risk factors and type 2 DM events are presented in Table 3.

Table 3. McNemar's test results of the independent variables and type $2 \mathrm{DM}$.

\begin{tabular}{llll}
\hline Variable & $\mathrm{p}$-value & OR & $95 \% \mathrm{Cl}$ \\
\hline Obesity & 0.001 & 7.7500 & $2.73-21.95$ \\
Smoking & 0.208 & 1.5833 & $0.76-3.26$ \\
$\begin{array}{l}\text { Physical } \\
\text { activity }\end{array}$ & 0.001 & 11.0000 & $3.37-35.86$ \\
$\begin{array}{l}\text { Family } \\
\text { history of } \\
\text { DM }\end{array}$ & 0.002 & 7.0000 & $2.45-19.95$ \\
\hline
\end{tabular}

The results in Table 3 show that the $p$-value between obesity and type 2 DM equals to 0.006 which means that there is a significant association between the two $(p<0.05)$. The analysis also obtained an $\mathrm{OR}$ value of $7.75(95 \% \mathrm{Cl}=2.73-21.95)$ which means that obesity is a risk factor for type 2 DM and that people who are obese have more than seven times the risk of developing type 2 DM as compared to people who are not obese.

The results of the bivariate analysis of smoking and type 2 DM events show a p-value of 0.208 (95\% $\mathrm{Cl}=0.76-3.26$ ) which means that there is no significant association between them. On the other hand, analysis between physical activity and type 2 DM obtained a $p$-value of 0.001 indicating a significant association between the two. The OR value for physical activity against type 2 DM events was $11.00(95 \% \mathrm{Cl}=3.37-35.86)$ which means that physical activity is a risk factor and that people who undertake less physical activity are 11 times as likely to suffer from type 2 DM compared to those who undertake enough.

A p-value of 0.002 was obtained through bivariate analysis of DM family history and type 2 DM events. This can be interpreted as showing significant association between DM history with type 2 DM. The results of the analysis show an OR value for these elements of 7.00 (95\% Cl=2.45-19.95) which means that family history is a risk factor and those who have such history are seven times as likely to suffer from type 2 DM compared to those who do not.

Subsequently, multivariate analysis in the form of Conditional Logistic Regression (CLR) was conducted to determine the association between all independent variables and type 2 DM events. The purpose of this analysis was to determine the most dominant risk factors associated with type 2 DM. The first CLR model can be seen in Table 4.

Table 4. Multivariate analysis between independent variables and type 2 DM (First model).

\begin{tabular}{llll}
\hline Variable & $\mathrm{p}$-value & OR & $95 \% \mathrm{Cl}$ \\
\hline Obesity & 0.014 & 6.27 & $1.45-27.11$ \\
$\begin{array}{l}\text { Smoking } \\
\text { Physical }\end{array}$ & 0.553 & 1.43 & $0.43-4.78$ \\
$\begin{array}{l}\text { activity } \\
\begin{array}{l}\text { Family } \\
\text { history of } \\
\text { DM }\end{array}\end{array}$ & 0.028 & 7.49 & $1.76-31.86$ \\
\hline
\end{tabular}

Table 4 shows that the first multivariate model returned a $p$-value for smoking of 0.553 ( $p>0.05)$; the smoking variable was therefore excluded from the second round of analysis. The final results the CLR analysis can be seen in Table 5 . 
Table 5. Multivariate analysis between independent variables and type 2 DM (Second model).

\begin{tabular}{llll}
\hline Variable & $\mathrm{p}$-value & $\mathrm{OR}$ & $95 \% \mathrm{Cl}$ \\
\hline Obesity & 0.013 & 6.44 & $1.48-27.93$ \\
Physical activity & 0.006 & 7.89 & $1.83-34.04$ \\
Family history of DM & 0.018 & 4.98 & $1.31-18.95$ \\
\hline
\end{tabular}

The information in Table 5 can be analyzed to determine the most dominant variable in relation to type 2 DM events in this study. Physical activity returned the highest $\mathrm{OR}$ value of the three at 7.89 (95\% Cl=1.83-34.04), showing that it is the most dominant risk factor associated with type 2 DM events. The 7.89 OR value means that people who undertake less physical activity have more than seven times the chance of developing type 2 DM than those who undertake enough, after being controlled by the obesity and family history variables.

\section{DISCUSSION}

Obesity is where body weight exceeds skeletal and physical requirements as a result of the accumulation of fat in the body. When body fat is more than $30 \%$ in women and $25 \%$ in men it is categorized as obesity, 13 and the prevalence of obesity is positively correlated with the incidence of diabetes. Fat deposits manifested as an increase in waist size encourage the development of degenerative diseases such as DM, an increase in plasma insulin, and insulin resistance syndrome ${ }^{6}$.

The prevalence of obesity and type 2 DM is rapidly increasing throughout the world, with around 60\% of obesity cases suffering from type $2 \mathrm{DM}$, and, the larger the body mass index (BMI), the greater the risk of developing the disease ${ }^{14}$. The results of the present study are in line with research conducted by Trisnawati and Setyorogo (2013) at the Cengkareng District Health Center in West Jakarta, Indonesia in which obesity was found to be a risk factor associated with the incidence of type $2 \mathrm{DM}$ $(p=0.006)$. BMI, together with other variables, has a significant association with DM, and the results of their OR calculations show that someone who is obese has a risk of developing diabetes. Indeed, the obese group had the greatest diabetes risk at 7.14 times greater than that of the normal BMI group $^{15}$.

Research conducted by Adnan, Mulyati, and Isworo (2013) in Tugurejo Hospital, Semarang, Indonesia showed that there is an association between BMI and blood sugar levels in type 2 DM patients $(p<0.05)^{16}$. Elsewhere, research conducted in rural India found that overweight or obese people are more prone to developing diabetes than those with normal $\mathrm{BMI}$ results $(\mathrm{B}: 0.388 ; 95 \% \mathrm{Cl} 0.147$ to
$0.628)^{17}$. The influence of $\mathrm{BMI}$ on the incidence of diabetes is the result of a lack of physical activity and the high consumption of carbohydrates, protein, and fat as risk factors for obesity. This increases the formation of cellular free fatty acids (FFAs) which then decreases the translocation of glucose transporters to the plasma membrane and causes insulin resistance in muscle and adipose tissue $^{18}$.

Physical activity is movement of the body which causes the simple expenditure of energy; it is very important for maintaining physical and mental health, as well as quality of life, by being healthy and fit. When engaged in physical activity, muscles use more glucose than when they are at rest, thus blood glucose concentration will decrease. Through physical activity, insulin works more effectively so that glucose can enter the cells to be burned as energy ${ }^{19}$. A study by Anani, Udiyono, and Ginanjar (2012) at Arjawinangun General Hospital in Cirebon Regency, Indonesia show a significant association between physical activity and the incidence of type 2 DM $(p=0.012)^{20}$. Comparable results were found by Wicaksono (2011) at the Internal Medicine Polyclinic of Dr. Kariadi, Indonesia where the key risk factor associated with type $2 \mathrm{DM}$ was found to be a lack of exercise $(p=0.038 \text { and } O R=3.00)^{21}$. Meanwhile, in the USA, diabetes risk was found to be lower in patients who walked with a brisk or striding style as compared to those who undertook none or walked at a casual pace (Hazard Ratio (HR) 0.67; $95 \% \mathrm{Cl} 0.54$ to 0.84 ), in those who undertook higher levels of exercise (HR for highest vs lowest quartile $0.79 ; 95 \% \mathrm{Cl} 0.63$ to 0.98 ), and in patients who took any compared to no vigorous physical activity (HR 0.79; $95 \% \mathrm{Cl} 0.66$ to 0.95$)^{22}$. Regular physical activity can increase insulin sensitivity and glucose tolerance, and it also has beneficial effects on body fat, blood pressure, fat distribution, and body weight, the various aspects of chronic metabolic syndrome, so that it can prevent cardiovascular disease ${ }^{23}$.

The risk of suffering from type $2 \mathrm{DM}$ if one parent has the disease is $15 \%$, and this rises to $75 \%$ if both parents are affected. The risk of developing DM is $10-30 \%$ greater in cases where the mother has it than in those where the father is the sufferer. This is due to a decrease in genes when in the womb is greater than the father. If a sibling has type $2 \mathrm{DM}$, there is a $10 \%$ risk of development in others, and, 
if identical twins are involved, the risk is $90 \% 24$. Research by Etika and Monalisa (2016) at Ngadiluwih Kediri Health Center, Indonesia shows a significant association between family history and the incidence of type $2 \mathrm{DM}^{25}$. Family history is therefore a useful detector for people with DM in their families. In theory, the disease is associated with chromosomes 3q, 15q, and 20q, and two potential loci have been identified, namely $7 p$ and $11 \mathrm{p}$. This may represent a genetic risk for $\mathrm{DM}^{26}$. In China, similar research found that DM history in immediate relatives is not only significantly related to the level of $B$-cell defects but also has a significant and independent rank correlation with the prevalence of diabetes in individuals. Multivariate logistic regression analysis here showed that the OR of having diabetes was 6.16 (95\% Cl: 4.46-8.50) and 2.86 (95\% Cl: 2.41-3.39) times higher in $\mathrm{FH} 2$ and $\mathrm{FH} 1$, respectively, than in FHO after adjustment for classical diabetes risk factors. FH2 and FH1: at least two generations and one generation of first-degree relatives with diabetes, respectively; FH0: no first-degree relatives with diabetes ${ }^{27}$.

Our study provides further proof of association between obesity, physical activity, and family history and the incidence of type 2 DM in Manado City, Indonesia. The city of Manado continues to grow rapidly every year, with the construction of buildings and entertainment venues such as malls that directly affect people's lifestyles. An unavoidable consequence of this is a change in diet which then results in obesity. Preventative changes in lifestyle are highly recommended to mitigate the increased risk of type $2 \mathrm{DM}$, particularly in terms of frequent physical activity to increase insulin sensitivity such as jogging, running, walking, or other aerobic exercise.

The case-control study design allowed more effective prediction of type 2 DM risk factors than a cross-sectional study. Nevertheless, we used retrospective information from medical records that have certain limitations in terms of the variables collected. This study has other limitations including the short period of data collection and small sample size. In future studies, a bigger sample from more health centers, a longer data collection period, different sociodemographic characteristics, and other clinical and metabolic factors could be considered to reduce these limitations.

\section{CONCLUSION}

Obesity, physical activity, and family history of DM are risk factors for type 2 DM events. The most dominant risk factor associated with type $2 \mathrm{DM}$ is physical activity so that people who undertake less physical activity are seven times more likely to develop the disease than those who do enough, after control for obesity and family history variables. Changes in daily lifestyle are highly recommended to prevent this increased risk of type $2 \mathrm{DM}$, in particular frequent physical activity to increase insulin sensitivity such as jogging, running, walking, or other aerobic exercise.

\section{ACKNOWLEDGEMENTS}

This study was supported and funded by Research and Community Service Institute of Sam Ratulangi University. We thank our colleagues from North Sulawesi Provincial Health Office, Manado City Health Office, Bahu Public Health Center, Ranotana Weru Public Health Center, Tikala Baru Public Health Center, Sario Public Health Center, and Teling Public Health Center for their assistance in data collection.

\section{REFERENCES}

1. United Nations Development Programme. Transforming Our World: The 2030 Agenda for Sustainable Development. 2015. [cited 2018 October 25]. Available from: http://www.un.org/ga/search/view_doc.a sp?symbol=A/RES/70/1\&Lang=E.

2. World Health Organization. Global Status Report on Noncommunicable Diseases 2014. Geneva: WHO Library Cataloguing-inPublication Data. 2014.

3. Bilous R \& Donelly R. Buku Pegangan Diabetes Edisi Ke 4. Jakarta: Bumi Medika. 2014.

4. International Diabetes Federation. One Adult in Ten Will Have Diabetes By 2030. 2011. [cited 2018 February 15]. Available from: http://www.idf.org/mediaevents/press-releases/2011/diabetesatlas-8th-edition

5. Suyono S. Buku Ajar Ilmu Penyakit Dalam Edisi 5. Jakarta: Interna Publishing. 2009.

6. Arisman. Obesitas, Diabetes Melitus, dan Dislipidemia: Konsep: Teori, dan Penanganan Aplikatif Seri Buku Ajar IImu Gizi. Jakarta: EGC. 2013.

7. American Diabetes Association. Living with Diabetes: Complications [Homepage on the Internet]. 2013. [cited 2018 February 18]. Available from: http://www.diabetes.org/living-withdiabetes/complications/eye-complications 
8. Irawan D. Prevalensi dan Faktor Risiko Kejadian Diabetes Melitus Tipe 2 di Daerah Urban Indonesia (Analisa Data Sekunder Riskesdas 2007). Jakarta: Fakultas Kesehatan Masyarakat Universitas Indonesia. 2010. [cited 2018 February 16]. Available from: http://www.lontar.ui.id/

9. World Health Organization. Global Status Report on Noncommunicable Diseases 2010. Geneva: WHO Library Cataloguing-inPublication Data. 2010.

10. Dinas Kesehatan Daerah Provinsi Sulawesi Utara. Profil Kesehatan Provinsi Sulawesi Utara Tahun 2016. Manado: Dinas Kesehatan Daerah Provinsi Sulawesi Utara. 2017.

11. Dinas Kesehatan Kota Manado. 10 Penyakit Menonjol Berdasarkan Surveilans Terpadu Puskesmas (STP) Kota Manado Tahun 2017. Manado: Dinas Kesehatan Kota Manado. 2018.

12. Badan Pusat Statistik Kota Manado. Kota Manado Dalam Angka 2018. Manado: Badan Pusat Statistik Kota Manado. 2018.

13. Hasdianah HR. Mengenal Diabetes Melitus pada Orang Dewasa dan Anak-anak dengan Solusi Herbal. Yogyakarta: Nuha Medika. 2012.

14. Tandra H. Segala Sesuatu yang Harus Anda Ketahui Tentang Diabetes: Panduan Lengkap Mengenal dan Mengatasi Diabetes dengan Cara Cepat dan Mudah. Jakarta: PT. Gramedia Pustaka Utama. 2008

15. Trisnawati SK \& Setyorogo S. Faktor Risiko Kejadian Diabetes Mellitus Tipe II di Puskesmas Kecamatan Cengkareng Jakarta Barat Tahun 2012. Jurnal Ilmiah Kesehatan Volume 5 Nomor 1. 2013. [cited by 2018 November 2]. Available from: http: / / fmipa.umri.ac.id/wpcontent/uploads/2016/06/YUNI-INDRIFAKTOR-RESIKO-DM.pdf

16. Adnan M, Mulyati T \& Isworo JT. Hubungan Indeks Massa Tubuh (IMT) dengan Kadar Gula Darah Penderita Diabetes Mellitus (DM) Tipe 2 Rawat Jalan di RS Tugurejo Semarang. Jurnal Gizi Universitas Muhammadiyah Semarang Volume 2 Nomor 1. 2013. [cited by 2018 November 2]. Available from: https://jurnal.unimus.ac.id/index.php/jgi zi/article/view/752
17. Barik A, Mazumdar S, Chowdhury A \& Rai RK. Physiological and behavioral risk factors of type 2 diabetes mellitus in rural India. BMJ Open Diabetes Research \& Care Volume 4 Issue 1. 2016. [cited by 2019 May 25]. Available from: https://drc.bmj.com/content/4/1/e00025 5

18. Teixeira-Lemos E, Nunes $S$, Texeira $F \&$ Reis $F$. Regular physical exercise training assists in preventing type 2 diabetes development: focus on its antioxidant and anti-inflammatory properties. Cardiovascular Diabetology Vol.10 No.12. 2011. [cited 2018 November 1]. Available from:

https://www.ncbi.nlm.nih.gov/pubmed/2 1276212

19. Soegondo S. Hidup Secara Mandiri dengan: Diabetes Mellitus, Kencing Manis, Sakit Gula. Depok: Fakultas Kedokteran Universitas Indonesia. 2008.

20. Anani S, Udiyono A \& Ginanjar P. Hubungan Antara Perilaku Pengendalian Diabetes dan Kadar Glukosa Darah Pasien Rawat Jalan Diabetes Melitus (Studi Kasus di RSUD Arjawinangun Kabupaten Cirebon). Jurnal Kesehatan Masyarakat Volume 1 Nomor 2. 2012. [cited 2018 November 2]. Available from: http: / /eprints.undip.ac.id/38380

21. Wicaksono RP. Faktor-faktor yang Berhubungan dengan Kejadian Diabetes Mellitus tipe 2. Semarang: Universitas Diponogoro. 2011.

22. Joseph JJ, Echouffo-Tcheugui JB, Golden $\mathrm{SH}$, Chen $\mathrm{H}$, Jenny NS, Carnethon MR, Jacobs Jr D, Burke GL, Vaidya D, Ouyang P \& Bertoni AG. Physical activity, sedentary behaviors and the incidence of type 2 diabetes mellitus: the Multi-Ethnic Study of Atherosclerosis (MESA). BMJ Open Diabetes Research \& Care Volume 4 Issue 1. [cited by 2019 May 25]. Available from: https://drc.bmj.com/content/4/1/e00018 5

23. Darmono, Suhartono T, Pemayun TGD \& Padmomartono FS. Naskah Lengkap Diabetes Melitus Ditinjau dari Berbagai Aspek Penyakit Dalam. Semarang: Badan Penerbit Universitas Diponegoro. 2007.

24. Diabetes UK. Diabetes in the UK: Key Statistics on Diabetes. London: Diabetes UK Central Office. 2010. 
25. Etika NA \& Monalisa V. Riwayat Penyakit Keluarga dan Kejadian Diabetes Mellitus. Jurnal Care Volume 4 Nomor 1. 2016. [cited 2018 November 2]. Available from: https://jurnal.unitri.ac.id/index.php/care /article/viewFile/473/468

26. American Diabetes Association. Classification and Diagnosis Diabetes Care [Homepage on the Internet]. 2017. [cited 2018 October 28]. Available from: http: //care.diabetesjournals.org/content/ 40/Supplement_1/S11

27. Zhang J, Yang Z, Xiao J, Xing X, Lu J, Weng J, Jia W, Ji L, Shan Z, Liu J, Tian H, Ji Q, Zhu D, Ge J, Chen J, Guo X, Zhao Z, Li Q, Zhou Z, Lin L, Wang $N$ \& Yang W. Association between Family History Risk Categories and Prevalence of Diabetes in Chinese Population. PLoS One Volume 10(2). 2015. [cited by 2019 May 25]. Available from: https://www.ncbi.nlm.nih.gov/pmc/articl es/PMC4321835/ 